\title{
ANALISIS DAN PEMETAAN KEMISKINAN MULTIDIMENSI PROVINSI SUMATERA BARAT
}

\author{
Yossi Windria \\ Universitas Andalas \\ e_mail : yossiwindria@bps.go.id
}

\begin{abstract}
This study aims to analyze poverty in West Sumatera Province using multidimensional approach. In multidimensional approach, poverty is measured and analyzed by considering the non-monetary dimension: health dimension, education dimension, and dimension of quality standard of living. The multidimensional poverty measurement in this study used the Alkire-Foster method was introduced by Alkire and Foster (2007) which was later adopted by UNDP to calculate the Multidimensional Poverty Index (MPI) as a permanent feature in the Human Development Report since 2010. Using the Susenas 2016 data, the following results are obtained: (1) The poverty condition is measured taking into account the non-monetary dimension giving a different picture than just taking into account the monetary dimension; (2) Poverty in West Sumatra is a rural phenomenon indicated by the dominance of higher deprived indicators in rural areas; (3) indicators of the use of cooking fuels, pre-school access, and sanitation are the indicators with the highest deprivation (inability of access) in the poor multidimensional population. From a poverty point of view in general, multidimensional poverty is relatively higher than that of monetary poverty. Therefore, multidimensional measurement is needed to complement the measurement of monetary poverty in order to provide a comprehensive picture of poverty estimation.
\end{abstract}

Keywords: multidimensional, household, health, education, quality of life

\section{PENDAHULUAN}

Dalam konteks kemiskinan selama ini, pengukuran kemiskinan selalu diukur melalui dimensi moneter yaitu pendekatan pengeluaran atau konsumsi rumah tangga. Sedangkan, kemiskinan dalam kerangka multidimensi diartikan melihat kemiskinan dari berbagai dimensi dan memandang penyebab kemiskinan dari berbagai sisi. Dibalik kemudahan operasionalnya, kemiskinan moneter menuai beberapa kritikan antara lain Sen (1980) yang menganggap bahwa pendekatan kemiskinan dengan menggunakan analisis moneter hanya memotret sebagian kecil dari begitu besarnya persoalan kemiskinan. Ketika masyarakat tidak bisa akses terhadap pelayanan kesehatan dasar dan pendidikan dasar akibat dari ketidakmampuan ekonomi maka itu bisa dikatakan miskin (Budiantoro dkk, 2013).

Laporan World Bank (2007) dalam ikhtisarnya tentang kemiskinan Indonesia menyebutkan bahwa kemiskinan dari segi nonpendapatan adalah masalah yang serius dibandingkan kemiskinan dari segi pendapatan. Apabila definisi kemiskinan diperluas hingga mencakup dimensi-dimensi lain kesejahteraan manusia, seperti kesehatan, pendidikan, tingkat konsumsi, dan akses infrastruktur dasar yang memadai, maka kemiskinan tetap akan menjadi isu utama di Indonesia. Hampir separuh penduduk Indonesia sekarang ini mengalami setidaknya satu jenis kemiskinan.

Sejalan dengan kondisi Indonesia pada umumnya, Provinsi Sumatera Barat pun 


\section{YOSSI WINDRIA}

\section{Analisis Dan Pemetaan Kemiskinan Multidimensi Provinsi Sumatera Barat}

memiliki jumlah penduduk miskin yang tidak sedikit. Menurut hasil pengumpulan data oleh BPS jumlah penduduk miskin Sumatera Barat cukup berfluktuasi yang menggambarkan bahwa ada bahagian masyarakat miskin yang masih terperangkap dalam kehidupan miskinnya. Oleh karena itu studi ini ingin melihat bagaimana gambaran kondisi kemiskinan multidimensi Provinsi Sumatera Barat dengan menggunakan metode AlkireFoster dan memetakannya sesuai dengan insiden kemiskinan multidimensi agar dapat dijadikan sebagai rekomendasi kebijakankebijakan pemerintah guna mengentaskan kemiskinan di Provinsi Sumatera Barat.

\section{REVIEW LITERATUR}

Ukuran kemiskinan moneter yang hanya mempertimbangkan kemiskinan dari variabel pendapatan atau pengeluaran saja, sedangkan ukuran kemiskinan multidimensional mempertimbangkan variabel ataupun dimensi lain selain pendapatan atau pengeluaran dalam pengukuran kemiskinannya. Menurut Sen (1985 \& 1999) yang mempelopori pendekatan ini, pembangunan seharusnya dilihat sebagai pengembangan kapasitas manusia (human capabilities), bukan peningkatan kegunaan (utility) atau pendapatan sebagai proksinya (Moko, 2014). Pemikiran Sen ini telah mempengaruhi dan memperluas pendekatan penghitungan kemiskinan mendasar dari yang berbasis income monetary approach menjadi berbasis capabilities yang mempertimbangkan multidimensi dari kemiskinan. Laderchi, Saith, \& Stewart (2003) menambahkan sumber moneter dipandang perlu tetapi bukan kondisi yang cukup untuk mencegah berlangsungnya rantai kemiskinan. Sehingga terdeprivasi berarti lebih dari ketidakmampuan untuk 'membeli' lebih (buy more) tetapi berarti ketidakmampuan untuk 'melakukan' lebih (do more).

Salah satu indeks yang paling populer dalam pengukuran kemiskinan multidimensi adalah Multidimensional Poverty Index (MPI) yang menjadi fitur tetap sejak tahun 2010 dalam publikasi tahunan Human Development Report oleh UNDP. MPI menerapkan metoda penghitungan kemiskinan multidimensional terbaru yaitu Alkire-Foster Methodology yang dikembangkan oleh Alkire dan Foster dengan menggunakan data level rumah tangga sehingga mampu mengetahui persentase penduduk yang mengalami kemiskinan dalam berbagai dimensi dan indikator. MPI meliputi tiga dimensi yaitu pendidikan, kesehatan, dan kualitas hidup dan terdapat sepuluh indikator yang dirujuk oleh UNDP. Namun dalam pengaplikasiannya, penghitungan MPI dengan metode Alkire-Foster membebaskan pemakaian indikator. UNDP memberikan kesempatan pada masing-masing negara untuk mengembangkan indikator MPI sesuai karakteristik kemiskinan yang terjadi di setiap negara. Indikator yang dipilih haruslah memenuhi standar yang tertuang dalam komponen SDGs. Bila ada indikator yang telah ditetapkan oleh UNDP tidak terdapat dalam sistem pendataan di suatu negara maka bisa dilakukan proksi terhadap indikator tersebut.

\section{Gambar 1}

\section{Dimensi dan Indikator MPI Alkire-Foster}

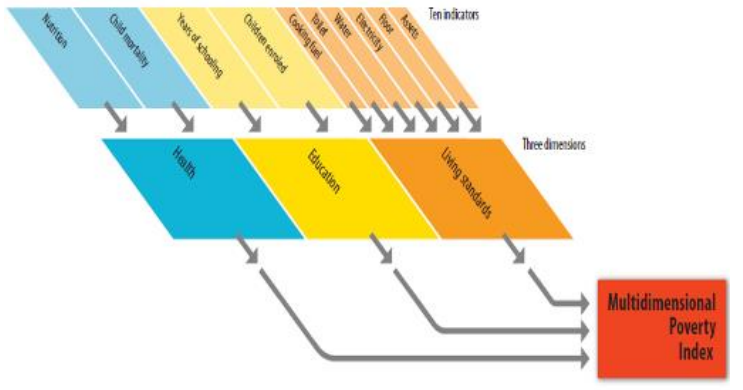

Sumber: Human Development Report UNDP (2010)

Menurut Alkire dan Seth (2009), penggunaan metode Alkire-Foster dalam penghitungan kemiskinan multidimensi memiliki beberapa keunggulan di antaranya:

1. cocok dan tepat diterapkan pada data ordinal atau data yang bersifat kategorik;

2. fokus pada kemiskinan dan deprivasi, memperlakukan setiap dimensi secara 


\section{JURNAL OPTIMUM, Volume 10, Nomor 1 Maret 2020}

independen terhadap dimensi lain tanpa mengasumsikan substitutabilitas antardimensi;

3. fleksibel untuk menerapkan pembobot yang setimbang atau berbeda pada dimensi yang berbeda tergantung pada kepentingan relatifnya; robust dalam mengidentifikasi individu termiskin dari penduduk miskin dengan menaikkan aggregate cut-off point;

4. informatif bagi kebijakan karena mampu menunjukkan dimensi apa yang dominan mempengaruhi kemiskinan multidimensi pada wilayah tertentu ataupun pada kelompok penduduk tertentu.

Penelitian ini mengadaptasi dimensi yang digunakan oleh Alkire dan Foster dengan pertimbangan bahwa ketiga dimensi yang digunakan tersebut adalah fungsi kapabilitas dasar manusia tapi ada beberapa indikator yang sedikit berubah yang disesuaikan dengan karakteristik penduduk miskin Indonesia (Budiantoro dkk, 2013). Sehingga dimensi dan indikator yang digunakan dalam penelitian ini adalah pada gambar 2 .

\section{Gambar 2}

Dimensi dan Indikator MPI Indonesia

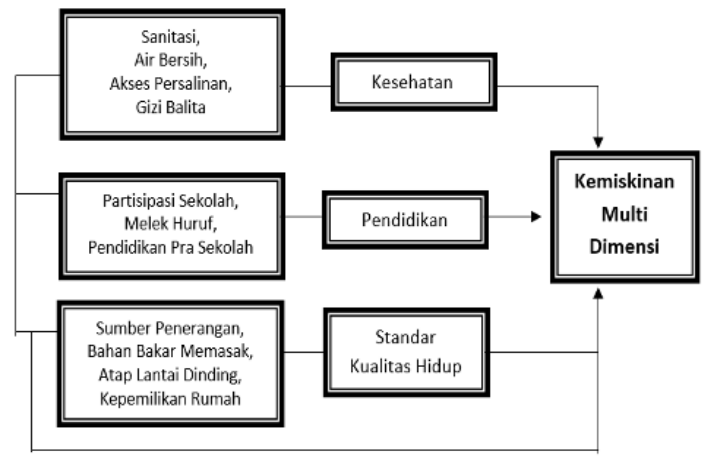

Sumber: Prakarsa (2015)

\section{METODE PENELITIAN}

Studi ini menggunakan data Susenas Tahun 2016 dari Badan Pusat Statistik dengan jumlah sampel 10.200 rumah tangga (ruta) yang tersebar di 19 Kabupaten/Kota di Provinsi Sumatera Barat. Pemilihan sampel rumah tangga (ruta) Susenas dilakukan dengan menggunakan multistage sampling (sampel bertingkat atau bertahap) dan seluruh sampel Susenas dicacah dengan menggunakan kuesioner K (keterangan pokok rumah tangga) dan kuesioner KP (konsumsi dan pengeluaran rumah tangga).

Untuk penghitungan dan pengukuran kemiskinan multidimensi dilakukan dengan menerapkan metode Alkire-Foster. Tahapan dalam metode Alkire-Foster dapat dijabarkan ke dalam 12 langkah (Alkire dan Foster, 2009):

1. Memilih unit analisis. Studi ini memakai unit analisis rumah tangga.

2. Memilih dimensi kemiskinan. Studi ini menggunakan tiga dimensi yaitu kesehatan, pendidikan, dan standar kualitas hidup.

3. Memilih indikator kemiskinan. Studi ini menggunakan sebelas indikator (gambar 2).

4. Menentukan cut-off/threshold deprivasi indikator (cut-off pertama).

5. Mengaplikasikan cut-off pertama pada indikator masing-masing rumah tangga.

6. Menghitung jumlah deprivasi untuk setiap unit analisis.

7. Menentukan garis kemiskinan (poverty cutoff) untuk mengindikasikan rumah tangga yang miskin multidimensi (cut-off kedua). Studi ini menggunakan poverty cut-off atau $\mathrm{k}=0,333$ dimana rumah tangga harus terdeprivasi minimal 33 persen dari jumlah deprivasi indikator untuk dikategorikan miskin secara multidimensi.

8. Mengaplikasikan garis kemiskinan (cut-off kedua) untuk memperoleh himpunan rumah tangga miskin dan menyensor data dari rumah tangga yang tidak miskin.

9. Menghitung nilai multidimensional poverty headcount $(\mathrm{H})$ yang merupakan persentase rumah tangga yang dikategorikan miskin multidimensi. $\mathrm{H}$ dapat juga diartikan sebagai angka kemiskinan multidimensi dengan definisi: $H=\frac{q_{k}}{n}$ dimana $q_{\mathrm{k}}=$ $\sum_{i=1}^{n} p_{k}\left(x_{i} ; z\right)=\sum_{i=1}^{n} \|\left(c_{i} \geq k\right)$, atau dengan kata lain qk adalah jumlah rumah tangga yang dikategorikan miskin 


\section{Analisis Dan Pemetaan Kemiskinan Multidimensi Provinsi Sumatera Barat}

multidimensi sedangkan $\mathrm{n}$ adalah total populasi rumah tangga.

10. Menghitung average deprivation shared across the poor (A) yang merupakan ratarata deprivasi yang dialami rumah tangga miskin. A dapat juga diartikan sebagai intensitas kemiskinan multidimensi dengan definisi: $\quad A=\frac{1}{q_{k} d} \sum_{i=1}^{n} c_{i} p_{k}\left(x_{i} ; z\right)$, atau dengan kata lain jumlah skor tertimbang dari deprivasi rumah tangga miskin multidimensi dibagi dengan jumlah rumah tangga miskin multidimensi.

11. Menghitung adjusted multidimensional poverty headcount $\left(\mathrm{M}_{0}\right)$ yang merupakan kombinasi dari $\mathrm{H}$ dan $\mathrm{A}$. $\mathrm{M}_{0}$ dapat juga diartikan sebagai indeks kemiskinan multidimensi. $\mathrm{M}_{0}$ dihitung dengan mengalikan $\mathrm{H}$ dengan A dengan rumusan: $M_{0}=H A=\frac{1}{n d} \sum_{i=1}^{n} c_{i} p_{k}\left(x_{i} ; z\right)$.

12. Mendekomposisi berdasarkan kelompok populasi maupun berdasarkan dimensi sesuai keperluan analisis. Dalam studi penelitian ini salah satu dekomposisinya adalah menurut indikator dilakukan dengan cara menghitung censored headcount ratio (CH) masing-masing indikator yang merupakan proporsi rumah tangga miskin multidimensi dan terdeprivasi pada masing-masing indikator. Sehingga kontribusi masing-masing indikator terhadap kemiskinan multidimensi dapat dihitung dengan definisi: Kontribusi indikator ke- $i$ terhadap $M_{0}=\frac{w_{j} C H_{j}}{M_{0}} * 100$ dimana $w_{j} C H_{j}$ adalah censored headcount ratio $(\mathrm{CH})$ masing-masing indikator yang dikalikan dengan bobot tertimbang (w) dari indikator pertama hingga ke-j.

Dimensi, titik potong, dan pembobot yang digunakan untuk membentuk indeks kemiskinan multidimensi dalam penelitian ini mengacu pada penelitian yang dilakukan Alkire dan Foster dengan modifikasi pada beberapa indikator dan titik potong/threshold serta mempertimbangkan ketersediaan data dalam Susenas K dan KP tahun 2016. Metode pembobotan dipakai rata-rata setiap dimensi dan indikator.

Berikut definisi dimensi dan indikator yang digunakan dalam studi penelitian ini sekaligus nilai bobot tertimbang masingmasing dimensi dan indikator (Tabel 1):

Tabel 1

\section{Definisi dan Bobot Dimensi dan Indikator MPI Indonesia}

\begin{tabular}{|c|c|c|c|c|}
\hline No & Dimensi & Indikator & Definisi & Cut-off/threshold \\
\hline (1) & (2) & (3) & (3) & (4) \\
\hline \multirow[t]{4}{*}{1.} & \multirow[t]{4}{*}{$\begin{array}{l}\text { Kesehata } \\
\mathrm{n} \\
(1 / 3= \\
0,333)\end{array}$} & $\begin{array}{l}\text { Sanitasi } \\
(1 / 12= \\
0,083)\end{array}$ & $\begin{array}{l}\text { Ketersediaan } \\
\text { dan jenis } \\
\text { jamban atau } \\
\text { kloset yang } \\
\text { digunakan oleh } \\
\text { ruta }\end{array}$ & $\begin{array}{l}\text { Kode 1: jika ruta akses } \\
\text { tempat pembuangan } \\
\text { air besar tidak ada, } \\
\text { umum, bersama, dan } \\
\text { sendiri. Jika sendiri } \\
\text { dengan jenis kloset } \\
\text { cemplung, cubluk, } \\
\text { atau tidak pakai kloset }\end{array}$ \\
\hline & & $\begin{array}{l}\text { Air Bersih } \\
(1 / 12= \\
0,083)\end{array}$ & $\begin{array}{l}\text { Sumber air } \\
\text { minum utama } \\
\text { yang } \\
\text { dipergunakan } \\
\text { sehari-hari oleh } \\
\text { ruta dan jarak } \\
\text { ke tempat } \\
\text { penampungan } \\
\text { limbah/kotoran } \\
\text { terdekat }\end{array}$ & $\begin{array}{l}\text { Kode 1: jika ruta akses } \\
\text { sumber air minum } \\
\text { utama dari sumur tak } \\
\text { terlindung, mata air } \\
\text { tak terlindung, air } \\
\text { sungai, air hujan, dan } \\
\text { lainnya. Jarak } \\
\text { penampungan limbah } \\
\text { akhir terhadap sumber } \\
\text { air utama < } 10 \text { meter }\end{array}$ \\
\hline & & $\begin{array}{l}\text { Akses } \\
\text { Layanan } \\
\text { Persalinan } \\
(1 / 12= \\
0,083)\end{array}$ & $\begin{array}{l}\text { Fasilitas } \\
\text { kesehatan yang } \\
\text { pernah dipakai } \\
\text { oleh ruta untuk } \\
\text { proses } \\
\text { melahirkan }\end{array}$ & $\begin{array}{l}\text { Kode } 1 \text { : jika ruta } \\
\text { mempunyai balita } \\
\text { yang proses } \\
\text { kelahirannya dibantu } \\
\text { oleh dukun bersalin, } \\
\text { famili/keluarga/tetang } \\
\text { ga, dan tenaga } \\
\text { penolong kelahirannya } \\
\text { lainnya (non medis) }\end{array}$ \\
\hline & & $\begin{array}{l}\text { Asupan } \\
\text { Gizi Balita } \\
(1 / 12= \\
0,083)\end{array}$ & $\begin{array}{l}\text { Jumlah kalori } \\
\text { per hari yang } \\
\text { dapat dipenuhi } \\
\text { oleh ruta yang } \\
\text { memiliki anak } \\
\text { balita }\end{array}$ & $\begin{array}{l}\text { Kode 1: jika ruta yang } \\
\text { memiliki anak balita } \\
\text { (0-6 tahun) dengan } \\
\text { asupan kalori < } 1600 \\
\text { kkal/hari }\end{array}$ \\
\hline \multirow[t]{2}{*}{2.} & \multirow[t]{2}{*}{$\begin{array}{l}\text { Pendidik } \\
\text { an } \\
(1 / 3= \\
0,333)\end{array}$} & $\begin{array}{l}\text { Partisipasi } \\
\text { Sekolah } \\
(1 / 9= \\
0,111)\end{array}$ & $\begin{array}{l}\text { Ruta yang } \\
\text { memiliki anak } \\
\text { usia sekolah } \\
\text { (7-18 tahun) } \\
\text { yang tidak } \\
\text { mampu } \\
\text { menjaga } \\
\text { keberlangsung } \\
\text { an pendidikan } \\
\text { formal } \\
\end{array}$ & $\begin{array}{l}\text { Kode 1: jika ruta } \\
\text { memiliki anak usia } \\
\text { sekolah ( } 7-18 \text { tahun) } \\
\text { tetapi tidak pernah } \\
\text { bersekolah atau tidak } \\
\text { bersekolah lagi }\end{array}$ \\
\hline & & $\begin{array}{l}\text { Melek } \\
\text { Huruf } \\
(1 / 9= \\
0,111)\end{array}$ & $\begin{array}{l}\text { Kemampuan } \\
\text { membaca dan } \\
\text { menulis setiap } \\
\text { anggota ruta di }\end{array}$ & $\begin{array}{l}\text { Kode } 1 \text { : jika ada } \\
\text { anggota ruta usia } \\
\text { produktif yang tidak } \\
\text { mampu membaca dan }\end{array}$ \\
\hline
\end{tabular}




\begin{tabular}{|c|c|c|c|c|}
\hline & & & $\begin{array}{l}\text { usia produktif } \\
(15-64 \text { tahun) }\end{array}$ & menulis \\
\hline & & \begin{tabular}{|l|} 
Akses \\
Layanan \\
Pendidikan \\
Pra \\
Sekolah \\
$(1 / 9=$ \\
$0,111)$
\end{tabular} & $\begin{array}{l}\text { Akses anggota } \\
\text { ruta yang } \\
\text { berusia 3-6 } \\
\text { tahun terhadap } \\
\text { pendidikan pra } \\
\text { sekolah (TK, } \\
\text { RA, kelompok } \\
\text { bermain, taman } \\
\text { penitipan anak, } \\
\text { dan kelas 1 } \\
\text { SD) }\end{array}$ & $\begin{array}{l}\text { Kode 1: jika ada } \\
\text { anggota ruta usia 3-6 } \\
\text { tahun yang tidak dapat } \\
\text { akses ke layanan } \\
\text { pendidikan pra } \\
\text { sekolah }\end{array}$ \\
\hline \multirow[t]{4}{*}{3.} & \multirow[t]{4}{*}{$\begin{array}{l}\text { Standar } \\
\text { Kualitas } \\
\text { Hidup } \\
(1 / 3= \\
0,333)\end{array}$} & $\begin{array}{l}\text { Sumber } \\
\text { Penerangan } \\
(1 / 12= \\
0,083)\end{array}$ & $\begin{array}{l}\text { Jenis sumber } \\
\text { penerangan } \\
\text { utama yang } \\
\text { dipergunakan } \\
\text { oleh ruta }\end{array}$ & $\begin{array}{l}\text { Kode 1: jika ruta } \\
\text { menggunakan sumber } \\
\text { penerangan berupa } \\
\text { listrik non PLN dan } \\
\text { bukan listrik }\end{array}$ \\
\hline & & $\begin{array}{l}\text { Bahan } \\
\text { Bakar } \\
\text { Memasak } \\
(1 / 12= \\
0,083)\end{array}$ & $\begin{array}{l}\text { Jenis bahan } \\
\text { bakar memasak } \\
\text { utama yang } \\
\text { digunakan } \\
\text { sehari-hari oleh } \\
\text { ruta }\end{array}$ & $\begin{array}{l}\text { Kode 1: jika ruta } \\
\text { menggunakan jenis } \\
\text { bahan bakar memasak } \\
\text { berupa minyak tanah, } \\
\text { lpiji } 3 \mathrm{~kg} \text {, briket, } \\
\text { arang, kayu bakar, dan } \\
\text { lainnya. }\end{array}$ \\
\hline & & \begin{tabular}{|l|} 
Kondisi \\
Atap, \\
Lantai, dan \\
Dinding \\
Bangunan \\
$(1 / 12=$ \\
$0,083)$
\end{tabular} & $\begin{array}{l}\text { Kondisi atap, } \\
\text { lantai, dan } \\
\text { dinding rumah } \\
\text { yang ditempati } \\
\text { ruta } \\
\text { berdasarkan } \\
\text { bahan/material } \\
\text { yang } \\
\text { digunakan }\end{array}$ & $\begin{array}{l}\text { Kode 1: jika rumah } \\
\text { yang ditempati ruta } \\
\text { dengan jenis atap: } \\
\text { ijuk/rumbia dan } \\
\text { lainnya; atau jenis } \\
\text { lantai: tanah/kayu } \\
\text { kualitas rendah/bambu } \\
\text { dan lainnya; atau jenis } \\
\text { dinding: } \\
\text { bambu/anyaman } \\
\text { bambu/batang kayu } \\
\text { dan lainnya. Terpenuhi } \\
\text { jika dua dari tiga } \\
\text { indikator di atas ada }\end{array}$ \\
\hline & & \begin{tabular}{|l|} 
Status \\
Kepemilika \\
n Rumah \\
$(1 / 12=$ \\
$0,083)$
\end{tabular} & \begin{tabular}{|l|} 
Status \\
kepemilikan \\
rumah tempat \\
tinggal sehari- \\
hari dimana \\
anggota ruta \\
beraktivitas \\
(makan dan \\
tidur)
\end{tabular} & $\begin{array}{l}\text { Kode 1: jika rumah } \\
\text { tempat tinggal anggota } \\
\text { ruta berstatus kontrak, } \\
\text { sewa, bebas sewa } \\
\text { milik orang lain, bebas } \\
\text { sewa milik } \\
\text { orangtua/sanak/saudar } \\
\text { a dan lainnya }\end{array}$ \\
\hline
\end{tabular}

HASIL PENELITIAN DAN PEMBAHASAN

Gambaran umum status deprivasi rumah tangga menurut indikator kemiskinan multidimensi tahun 2016 dapat disajikan pada Tabel 2 dibawah ini:
Tabel 2

\section{Persentase Status Deprivasi Rumah} Tangga Menurut Indikator Kemiskinan Multidimensi di Provinsi Sumatera Barat

\begin{tabular}{|c|c|c|c|}
\hline Indikator & Sta & tus & \\
\hline $\begin{array}{l}\text { Kemiskinan } \\
\text { Multidimensi }\end{array}$ & $\begin{array}{c}\text { Tidak } \\
\text { Terdeprivasi }\end{array}$ & Terdeprivasi & Total \\
\hline (1) & (2) & (3) & (4) \\
\hline Sanitasi & 66,55 & 33,45 & 100,0 \\
\hline Air bersih & 63,93 & 36,07 & 100,0 \\
\hline $\begin{array}{l}\text { Layanan } \\
\text { persalinan }\end{array}$ & 96,35 & 3,65 & 100,0 \\
\hline $\begin{array}{ll}\begin{array}{l}\text { Asupan gizi } \\
\text { balita }\end{array} \\
\end{array}$ & 77,88 & 22,12 & 100,0 \\
\hline $\begin{array}{l}\text { Partisipasi } \\
\text { sekolah }\end{array}$ & 92,35 & 7,65 & 100,0 \\
\hline Melek huruf & 97,16 & 2,84 & 100,0 \\
\hline $\begin{array}{l}\text { Pendidikan } \\
\text { pra sekolah }\end{array}$ & 38,81 & 61,19 & 100,0 \\
\hline $\begin{array}{l}\text { Sumber } \\
\text { penerangan }\end{array}$ & 93,92 & 6,08 & 100,0 \\
\hline $\begin{array}{l}\text { Bahan bakar } \\
\text { memasak }\end{array}$ & 9,94 & 90,06 & 100,0 \\
\hline $\begin{array}{l}\text { Kondisi atap, } \\
\text { lantai, dinding } \\
\text { rumah }\end{array}$ & 98,38 & 1,62 & 100,0 \\
\hline $\begin{array}{l}\text { Status } \\
\text { kepemilikan } \\
\text { rumah }\end{array}$ & 75,91 & 24,09 & 100,0 \\
\hline
\end{tabular}

Sumber: hasil olah data Susenas 2016

Proporsi rumah tangga yang terlihat sangat tinggi (lebih dari 50 persen) tercatat pada indikator jenis bahan bakar memasak dan akses layanan pendidikan pra sekolah, dimana masing-masing indikator terdeprivasi sebesar 90,06 persen dan 61,19 persen. Selain itu, rumah tangga yang terdeprivasi pada indikator air bersih, sanitasi, asupan gizi balita, dan status kepemilikan rumah juga masih cukup tinggi (lebih 20 persen).

Menurut World Bank (2009) kemiskinan di Asia pada dasarnya merupakan fenomena pedesaan bahkan beberapa negara 80 hingga 90 persen penduduk miskin berada di daerah pedesaan. Fenomena tersebut juga ditemukan di Provinsi Sumatera Barat. Tampak pada hasil 
perhitungan kemiskinan multidimensi yang tersaji pada tabel 3.

Tabel 3

Indikator Kemiskinan Multidimensi Menurut Klasifikasi Daerah

\begin{tabular}{|l|c|c|c|}
\hline $\begin{array}{c}\text { Klasifikasi } \\
\text { Daerah }\end{array}$ & $\begin{array}{c}\mathrm{H} \\
(\%)\end{array}$ & $\begin{array}{c}\mathrm{A} \\
(\%)\end{array}$ & $\begin{array}{c}\mathrm{M}_{0} \\
(\%)\end{array}$ \\
\hline Perkotaan & $(2)$ & $(3)$ & $(4)$ \\
\hline Pedesaan & 22,19 & 37,83 & 3,62 \\
\hline $\begin{array}{l}\text { Sumatera } \\
\text { Barat }\end{array}$ & 17,01 & 38,96 & 8,72 \\
\hline
\end{tabular}

Sumber: hasil olah data Susenas 2016

Proporsi rumah tangga miskin $(\mathrm{H})$ di daerah pedesaan lebih tinggi dibandingkan proporsi rumah tangga miskin daerah perkotaan. Bahkan, kemiskinan yang dialami rumah tangga miskin pedesaan lebih dalam daripada rumah tangga miskin perkotaan. Hal ini dapat dilihat dari persentase A daerah pedesaan yang lebih tinggi dari perkotaan. Dengan kata lain, rumah tangga miskin pedesaan mengalami deprivasi pada indikator yang lebih banyak daripada rumah tangga miskin di perkotaan. Dengan proporsi dan intensitas kemiskinan yang lebih tinggi, maka daerah pedesaan pun memiliki tingkat kemiskinan multidimensi $\left(\mathrm{M}_{0}\right)$ yang lebih tinggi daripada daerah perkotaan.

Untuk kontribusi dimensi terhadap kemiskinan multidimensi menurut klasifikasi daerah terlihat jelas bahwa kemiskinan daerah pedesaan dijelaskan oleh dimensi kesehatan sebesar 42,76 persen dan untuk indikator, sumbangsih paling tinggi di wilayah pedesaan adalah indikator bahan bakar memasak sebesar 21,19 persen. Persoalan ini mengindikasikan bahwa dimensi kesehatan masih menjadi salah satu isu penting dalam usaha mengurangi kemiskinan di Sumatera Barat. Ariningsih (2008) mengemukakan bahwa kekurangan konsumsi gizi bagi seseorang dari standar minimum berpengaruh terhadap kondisi kesehatan, aktivitas, dan produktivitas kerja. Dalam jangka panjang, kekurangan konsumsi pangan dari segi jumlah dan kualitas terutama pada balita akan mempengaruhi kualitas sumber daya manusia sehingga akan mempengaruhi pencapaian kesejahteraan rumah tangga.

Untuk daerah perkotaan, kontribusi dimensi terhadap kemiskinan multidimensi dijelaskan oleh dimensi kualitas hidup $(39,14$ persen), diikuti dimensi kesehatan $(36,45$ persen), dan dimensi pendidikan (24,41 persen). Sedangkan untuk indikator, sumbangsih paling tinggi di wilayah perkotaan adalah indikator bahan bakar memasak sebesar 21,97 persen.

Tabel 4

Persentase Kontribusi Indikator terhadap Kemiskinan Multidimensi Menurut Klasifikasi Daerah di Provinsi Sumatera Barat

\begin{tabular}{|l|c|c|}
\hline \multicolumn{1}{|c|}{ Dimensi/Indikator } & Perkotaan & Pedesaan \\
\hline Dimensi Kesehatan & $\mathbf{3 6 , 4 5}$ & $\mathbf{4 2 , 7 6}$ \\
\hline Sanitasi & 14,14 & 18,14 \\
\hline Air bersih & 11,32 & 17,88 \\
\hline Persalinan & 0,23 & 0,71 \\
\hline Gizi balita & 10,77 & 6,03 \\
\hline $\begin{array}{l}\text { Dimensi } \\
\text { Pendidikan }\end{array}$ & $\mathbf{2 4 , 4 1}$ & $\mathbf{2 1 , 1 9}$ \\
\hline Partisipasi sekolah & 3,44 & 4,86 \\
\hline Melek huruf & 2,94 & 2,31 \\
\hline Pra sekolah & 18,03 & 14,73 \\
\hline $\begin{array}{l}\text { Dimensi Kualitas } \\
\text { Hidup }\end{array}$ & $\mathbf{3 9 , 1 4}$ & $\mathbf{3 5 , 3 3}$ \\
\hline Penerangan & 1,93 & 5,34 \\
\hline $\begin{array}{l}\text { Bahan } \\
\text { memasak }\end{array}$ & 21,97 & 21,19 \\
\hline Kondisi rumah & 1,60 & 1,64 \\
\hline Status rumah & 13,64 & 7,16 \\
\hline
\end{tabular}

Sumber: hasil olah data Susenas 2016

Kontribusi indikator bahan bakar memasak yang masih mendominasi sebagai penyumbang kemiskinan multidimensi tertinggi pada kedua tipe daerah sejalan dengan penelitian Saghir (2005) yang berpendapat bahwa rumah tangga miskin menghabiskan lebih besar bagian pendapatan mereka yakni sekitar 15-20 persen untuk penggunaan energi 
dibanding rumah tangga berpenghasilan menengah ke atas yang hanya 5 persen.

Penggunaan peta kemiskinan memberikan kemudahan untuk mengamati insiden kemiskinan antar wilayah. Persentase rumah tangga miskin tiap Kabupaten/Kota dikategorikan dalam empat kategori yaitu rendah $(<15,00$ persen), sedang $(15,00-24,99$ persen), tinggi (25,00-34,99 persen), dan sangat tinggi ( $\geq 35,00$ persen). Gambar 3 dan 4 memetakan persentase rumah tangga miskin secara multidimensi menurut klasifikasi daerah (perkotaan dan pedesaan) dan Kabupaten/Kota di Provinsi Sumatera Barat tahun 2016.

\section{Gambar 3}

Peta Persentase Rumah Tangga Miskin Multidimensi Perkotaan Menurut Kabupaten/Kota di Provinsi Sumatera Barat

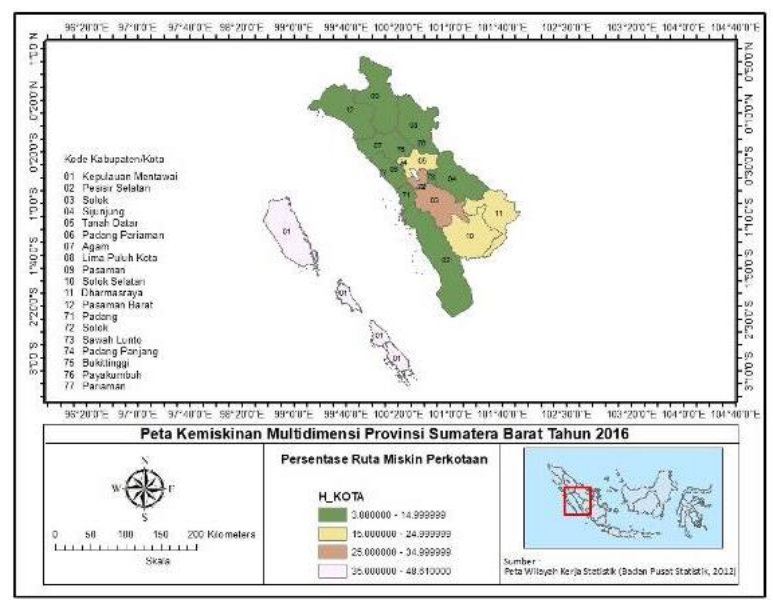

Sumber: hasil olah data Susenas 2016

Dengan pengelompokkan empat kategori diatas, pada gambar 4 diperoleh persentase rumah tangga miskin multidimensi perkotaan berkategori sangat tinggi (pink muda) terdapat di Kabupaten Kepulauan Mentawai; untuk kategori tinggi (merah bata) berada di Kabupaten Solok; selanjutnya untuk kategori sedang (kuning) terdapat di Kabupaten Tanah Datar, Solok Selatan, dan Dharmasraya; sedangkan sisanya (7 Kabupaten dan 7 Kota) berkategori rendah (hijau).
Pada Gambar 5 diperoleh persentase rumah tangga miskin multidimensi pedesaan berkategori rendah (hijau) terdapat pada 6 wilayah Kota yaitu Sawahlunto, Solok, Padang, Bukittinggi, Pariaman, dan Payakumbuh; untuk kategori sedang (kuning) terdapat di Kota Padang Panjang dan 8 Kabupaten yaitu Pesisir Selatan, Pasaman Barat, Dharmasraya, Solok Selatan, Lima Puluh Kota, Agam, Padang Pariaman, dan Tanah Datar; sedangkan untuk kategori tinggi (merah bata) terdapat Kabupaten Solok dan Kabupaten Sijunjung; selanjutnya untuk kategori sangat tinggi (pink muda) masih terdapat Kabupaten Kepulauan Mentawai dan ditambah dengan Kabupaten Pasaman.

\section{Gambar 4}

Peta Persentase Rumah Tangga Miskin Multidimensi Perkotaan Menurut Kabupaten/Kota di Provinsi Sumatera Barat

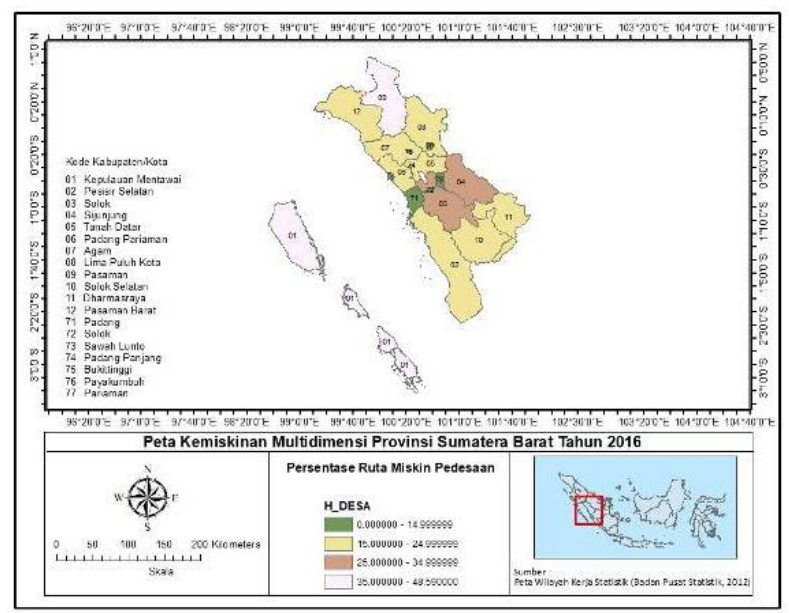

Sumber: hasil olah data Susenas 2016

\section{KESIMPULAN DAN SARAN}

\section{Kesimpulan}

Isu kemiskinan menjadi penting bukan hanya karena alasan untuk mencapai tujuan pembangunan berkelanjutan tetapi juga untuk meningkatkan kapabilitas rumah tangga agar berkemampuan akses kepada dimensi-dimensi strategis guna menjamin keberlangsungan hidup dan masa depan. Gambaran umum deprivasi yang dialami rumah tangga di 


\section{YOSSI WINDRIA}

\section{Analisis Dan Pemetaan Kemiskinan Multidimensi Provinsi Sumatera Barat}

Provinsi Sumatera Barat terlihat sangat tinggi pada indikator jenis bahan bakar memasak dan akses layanan pendidikan pra sekolah dengan jumlah rumah tangga terdeprivasi lebih dari 50 persen dari total rumah tangga yang ada di Sumatera Barat. Selain itu, deprivasi pada indikator lain seperti air bersih, sanitasi, asupan gizi balita, dan status kepemilikan rumah juga perlu mendapatkan perhatian lebih.

\section{Saran}

Hasil analisis lain berupa komparasi angka kemiskinan multidimensi dengan angka kemiskinan moneter menunjukkan adanya kecenderungan bahwa kemiskinan multidimensi memiliki angka yang lebih tinggi dibandingkan kemiskinan moneter. Oleh karena itu, pengukuran multidimensi atau nonmoneter diperlukan guna melengkapi pengukuran kemiskinan moneter agar mampu memberikan gambaran yang lebih komprehensif dalam mengestimasi kemiskinan. Metode pengukuran kemiskinan dengan mempertimbangkan aspek nonmoneter (multidimensional) memungkinkan untuk menjadi dasar penentuan target rumah tangga atau kelompok penerima berbagai bantuan penanggulangan kemiskinan. Meskipun demikian, masih diperlukan studi khusus untuk mengidentifikasi rumah tangga penerima program bantuan dengan dimensi yang benar-benar relevan dengan kriteria program bantuan dan hal ini dapat terwujud tentunya dengan kerjasama dan batuan dari pemerintah dan stakeholder terkait.

\section{DAFTAR PUSTAKA}

Alkire, Sabina \& Foster, James. 2009. The Poorest and Hungry: Assessment, Analysis and Actions, Chapter 3, Counting and Multidimensional Poverty Measurement. Washington : The International Food Policy Research Institute (IFPRI).

Alkire, Sabina. \& Seth, Suman. 2009. Measuring Multidimensional Poverty in India: A New Proposal. OPHI Working
Paper No. 15 September 2008 (Rev. May 2009). Oxford University : Oxford Poverty and Human Development Initiative (OPHI).

Ariningsih, Ening. 2008. Konsumsi dan Kecukupan Energi dan Protein Rumah Tangga Pedesaan di Indonesia: Analisis Data Susenas 1999, 2002, 2005. Paper disajikan dalam Seminar Nasional Dinamika Pembangunan Pertanian dan Pedesaan 19 November 2008. Bogor.

Budiantoro, Setyo dkk. 2013. Multidimensional Poverty Index (MPI): Konsep dan Pengukurannya di Indonesia, PRAKARSA Economics Policy Working Paper. Jakarta: Perkumpulan PRAKARSA.

Laderchi, C.R. Saith, R. \& Stewart, F. 2003. Does It Matter That We Don't Agree on the Definition of Poverty? A Comparison of Four Approaches. Working Paper Number 107, May 2003.

Moko, Fransiska Engelina. 2014. Kemiskinan Multidimensi Dalam Perspektif Gender di Indonesia. Tesis. Program Pascasarjana Mutidisiplin Kajian Kependudukan dan Ketenagakerjaan. Universitas Indonesia. Depok.

PRAKARSA. 2015. Laporan Dimensi, Indikator, dan Perhitungan Multidimensional Poverty Index (MPI) Indonesia. Jakarta: Perkumpulan PRAKARSA.

Saghir, Jamal. 2005. Energy and Poverty: Myths, Links, and Policy Issues. Energy Working Notes No. 4 May 2005. Energy and Mining Sector Board: The World Bank Group.

UNDP. 2010. Human Development Report 2010. The Real Wealth of Nations: Pathways to Human Development. New York. USA.

World Bank. 2007. Era Baru dalam Pengentasan Kemiskinan di Indonesia. Jakarta: The World Bank Office Jakarta.

World Bank. 2009. The World Bank Annual Report 2009 Year in Review. Washington DC. The World Bank. 